\title{
U.S. Consumers and Electronic Banking, 1995-2003
}

Christoslav E. Anguelov, Marianne A. Hilgert, and Jeanne M. Hogarth, of the Board's Division of Consumer and Community Affairs, prepared this article.

The variety of electronic banking technologies available in the marketplace has greatly expanded in recent years. For financial institutions, such technologies as direct deposit, automated teller machines, and debit cards can speed processing and reduce costs. Other products and services, for example, computer banking and stored-value payroll cards, are viewed as ways to retain existing customers and attract unbanked and underbanked consumers. From the consumer's perspective, choosing to use electronic banking (e-banking) technologies can mean easier and lower-cost bill-paying, around-the-clock availability of financial services, and time savings in managing finances. For some consumers, e-banking may not be a matter of choice, as more and more financial transactions are being conducted in an "electronic only" format.

Research suggests that consumer acceptance and use of e-banking technologies are related to the characteristics of both the individual consumer and the specific technology. For example, acceptance appears to be associated with a consumer's socioeconomic and demographic characteristics (such as income and age), perceptions of specific technologies (such as perceived ease of use), and personal preferences (such as desire for control over when a bill is paid).

This article draws on data from two nationwide surveys-the Board's Survey of Consumer Finances and the University of Michigan Survey Research Center's Surveys of Consumers-to look at consumer use of e-banking technologies, particularly as it relates to consumer demographic characteristics and perceptions, and the relationship between these factors and the characteristics of selected e-banking products and services. By combining data from these two periodic surveys, the article examines changes in consumers' use of e-banking technologies between 1995 and 2003, a period of substantial change and

Note. Christopher Calice, of the University of California-Davis, and Mary E. Gibson, of Georgetown University, Washington, D.C., provided assistance with background research. growth in the electronic financial services marketplace, and shifts in perceptions in recent years. (For information on the two data sets, see appendix A.) The article concludes with a discussion of the implications of trends in the use of e-banking for consumer educators.

\section{E-BANKING TECHNOLOGIES}

Electronic banking encompasses a broad range of established and emerging technologies. Some are "front end" products and services that consumers opt for, such as ATM cards and computer banking; others are "back end" technologies used by financial institutions, merchants, and other service providers to process transactions, such as electronic check conversion. Some are tied to a consumer bank account; others are unrelated to a bank account but instead store monetary value in a database or directly on a card. ${ }^{1}$ As the e-banking marketplace has evolved, the distinctions between products have blurred; for example, one plastic card having a magnetic strip may be tied to a bank account and another may store monetary value, but both may be referred to by merchants and vendors as "debit cards." Described here are the most common products and services used by consumers (other electronic banking technologies and related terms are described in the box "Glossary of E-Banking Terms").

\section{Products Related to Bank Accounts}

According to the 2001 Survey of Consumer Finances (SCF), about nine out of ten U.S. households have a bank account, and nearly all households within that group (93 percent) have at least one electronic fund

1. Generally, electronic products and services tied to a consumer bank account are covered by the federal Electronic Fund Transfer Act (EFTA) and the Federal Reserve Board's Regulation E and those not tied to a bank account are not. See box "E-Banking and Consumer Protection." Some so-called debit cards not tied to a bank account are actually stored-value cards, although consumers may use them in card readers and at ATMs in the same way they use debit cards tied to an account; these cards generally are not covered by the EFTA. 


\section{Glossary of E-Banking Terms}

Automated teller machine (ATM). An electronic terminal provided by financial institutions and other firms that permits consumers to withdraw cash from their bank accounts, make deposits, check balances, and transfer funds.

Computer banking. Banking services that consumers can access, by using an Internet connection to a bank's computer center, in order to perform banking tasks, receive and pay bills, and so forth. Many other financial services can be accessed via the Internet (for example, paying credit card bills on a credit card issuer's web site), but those services may not be classified as computer banking.

Debit (or check) card. A card used at an ATM or a point-of-sale (POS) terminal that enables a consumer to have funds directly debited from his or her bank account (usually a checking account). Some financial service providers (such as check cashers and currency exchanges) may market a so-called debit card that is not tied to a deposit account but instead functions as a stored-value card.

Direct deposit. A form of payment by which an organization (such as an employer or a government agency) pays funds (such as pay or benefits) via an electronic transfer. The funds are transferred directly into a consumer's bank account.

Direct payment (also electronic bill payment). A form of payment that allows a consumer to pay bills through electronic fund transfers. Funds are electronically transferred from the consumer's account to the creditor's account. A direct payment differs from a preauthorized debit in that the consumer must initiate each direct payment transaction.

Electronic bill presentment and payment (EBPP). A form of bill payment by which bills are presented to a customer online, via either e-mail or a notice in an e-banking account. After presentment, the customer may pay the bill online when convenient. The payment is electronically deducted from the customer's account.

Electronic check conversion. The process by which information from a check (routing number, account number, and amount of the transaction) is converted into electronic for-

Note. The definitions in this glossary are meant to give a general understanding of terms used in electronic banking. They are not legal definitions, but they generally assume compliance with applicable legal requirements. The terms may be used differently in different situations, and their exact definition under federal law may differ from that under state law. These definitions are generally consistent with those in the "Glossary of Terms Used in Payments and Settlement Systems" issued by the Bank for International Settlements (www.bis.org/publ/cpss00b.htm) but are less technical. mat in order to make a one-time electronic fund transfer from an account. ${ }^{1}$

Electronic fund transfer (EFT) The movement of "money," or credits, from one account to another through an electronic medium.

Payroll card. A type of stored-value card issued by an employer instead of a paycheck that enables an employee to access his or her pay at ATMs or point-of-sale terminals. The employer adds the value of the employee's pay to the card electronically.

Preauthorized debit (or automatic bill payment). A form of payment that allows a consumer to authorize automatic payment of regular, recurring bills from his or her account on a specific date, and usually for a specific amount (for example, car payments, housing payments, and budget-plan utility bills). The funds are electronically transferred from the consumer's account to the creditor's account.

Prepaid card. A stored-value card on which monetary value is stored and for which the consumer has paid the issuer in advance.

Smart card. A type of stored-value card in which one or more chips or microprocessors are embedded, making the card capable of storing data, performing calculations, or performing special-purpose processing (to validate personal identification numbers, authorize purchases, verify account balances, and store personal records). The memory in some smart cards is updated when the card is used. The chip or microprocessor physically stores records, such as the value of funds remaining on the card. These cards can be used in "closed" systems (for example, a transit system) or "open" systems (for example, MasterCard or Visa networks).

Stored-value card. A card on which monetary value is stored, through either prepayment by a consumer or deposit by an employer or other entity. For a single-purpose storedvalue card, the card issuer and acceptor are generally the same entity, and the funds on the card represent prepayment for specific goods and services (for example, a phone card). A limited-purpose card is generally restricted to wellidentified points of sale within a given location (for example, vending machines at a university). A multi-purpose card can be used at several service providers for a wide range of purposes; it may carry a MasterCard or Visa logo or the logo of another interbank network.

1. For a more complete description of electronic check conversion, see the consumer publication "When Is Your Check Not a Check?" (www.federalreserve.gov/pubs/checkconv/default.htm). 
transfer feature-direct deposit, an ATM or debit card, or computer banking, for example-associated with their account.

Direct deposit. Nearly two-thirds of all employees in the United States have their pay deposited directly into a bank account. ${ }^{2}$ And more than fourfifths of social security recipients have benefits deposited directly into their account, thanks in part to the U.S. Department of the Treasury's EFT '99 initiative to increase the number of federal payments made electronically. ${ }^{3}$ A part of that initiative was development of the all-electronic Electronic Transfer Account (ETA), a consumer bank account that allows federal benefit recipients to access their funds via ATMs and at point-of-sale terminals. ${ }^{4}$ According to the Treasury Department, more than 74,000 ETAs had been opened as of October 2003.5

ATM cards. ATM cards, which consumers can use to access their bank accounts at an electronic terminal, were introduced in the late 1960s to help consumers make cash withdrawals from their deposit accounts; by 2003, about 902 million ATM transactions were being processed each month, up slightly from the 2002 monthly average. Consumers are using ATMs not only at their local banks, but at other locations in their neighborhoods and throughout the world. In 2003, more than 64 percent of ATMs were located off bank premises. ${ }^{6}$

Debit cards. Debit cards linked to a bank account, sometimes referred to as check cards, can be used at ATMs as well as at points of sale and over the Internet. The multiple uses of debit cards have contributed to the technology's increasing popularity. Between 1995 and 2002, the number of debit card transactions in the United States grew nearly 42 percent a year. ${ }^{7}$ By 2003, the number of point-of-sale debit transactions stood at 495 million a month, up 21 percent from $2002 .{ }^{8}$

2. NACHA-The Electronic Payments Association (formerly National Automated Clearing House Association), Direct Deposit/ Direct Payment General Information, 2nd ed. (NACHA, June 2003).

3. Social Security Administration, "Social Security Administration Beneficiaries, Social Security Direct Deposit and Check Statistics" (www.ssa.gov/deposit/GIS/data/Reports/T2StateSum.htm).

4. Development of the ETA was a cooperative effort between the Treasury Department and financial institutions. These accounts carry a maximum \$3 a month fee; for other details, see www.fms.treas.gov/ eta/index.html.

5. Financial Management Service, U.S. Department of the Treasury.

6. EFT Data Book: The Complete Guide to the ATM and POS Debit Markets, vol. 3, no. 44 (Thompson Media, September 2003).

7. Geoffrey R. Gerdes and Jack K. Walton II, "The Use of Checks and Other Noncash Payment Instruments in the United States," Federal Reserve Bulletin, vol. 88 (August 2002), pp. 360-74.

8. EFT Data Book.
Preauthorized debits. Preauthorized debits allow consumers to have regular, recurring bills automatically paid on a specific date (for example, a consumer can have car payments automatically debited on the tenth of the month for the life of the lease or loan). The funds are electronically transferred from the consumer's account to the creditor or payee. Unlike ATM cards and debit cards, which are "active" technologies in that consumers must interact with the technology while using it, preauthorized debits can be thought of as a "passive" technology; once the process has been established, the consumer does not need to do anything more until a change is desired (for example, a change in the payment date).

Computer banking. Using computer banking, consumers can access their bank accounts to transfer funds, pay bills, check account balances, review account statements, and conduct other banking business, such as ordering checks and issuing stoppayment orders. Early forms of computer banking involved dial-up connections directly with a bank's computer; now nearly all computer banking is based on Internet connections. Consumers also use the Internet to conduct other personal financial business, such as monitoring investment accounts, reviewing credit card statements, and shopping for credit, investment, and insurance products. Consumers may be able to make electronic fund transfers from either their bank's computer banking program or their financial service's web site; for example, they may be able to pay their credit card bills through either their bank's computer banking service or their credit card company's web site.

\section{Products Not Related to Bank Accounts}

Electronic products that are not tied to a consumer bank account but instead store monetary value in a related database or on a card include prepaid cards (such as phone and gift cards), payroll cards, college and military cards, cards used to deliver insurance benefits to disaster victims, and cards used by states to deliver child support payments. These cards can look much like traditional debit cards (for example, they may carry a MasterCard or Visa logo) and may even be called debit cards by merchants and vendors.

Stored-value cards have been around since the 1970s. They were originally issued as single-purpose cards for low-value transactions but are now popular as higher value, broadly usable cards. Most storedvalue cards have a magnetic strip that links the card to a monetary value stored in a database. Some are reloadable. They can be used in "closed systems," 


\section{E-Banking and Consumer Protection}

The Electronic Fund Transfer Act (EFTA) is the major federal consumer protection law covering electronic banking transactions. It covers most electronic fund transfer (EFT) products and services associated with a consumer bank account, such as ATM and debit cards and computer banking.

Under the provisions of Federal Reserve Board Regulation E (Electronic Fund Transfers), which implements the act, when you use an ATM card to withdraw money from or make deposits to your bank account, or use a debit card at a point-of-sale (POS) terminal to pay for a purchase with money from your bank account, you must receive a written receipt giving such information as the amount of the transfer, the date it was made, and the location of the terminal. This receipt is your record of transfers initiated at an electronic terminal. You can compare this receipt with your periodic bank account statement, which must show electronic fund transfers to and from your account, including those made with an ATM or debit card, by a preauthorized debit, under a telephone transfer plan, or as a computer banking transaction. The statement must also identify the party to whom payment was made and show any EFT service fees.

Consumer liability limits for unauthorized transfers involving ATM and debit cards linked to a bank account are different from the limits for the unauthorized use of credit cards. The federal limit for consumer liability on a lost or stolen credit card is $\$ 50 .{ }^{1}$ Under Regulation E, the limit for an unauthorized transfer by an ATM card, debit card, or other access device linked to a bank account can vary:

- Your loss is limited to $\$ 50$ if you notify the financial institution that issued the card within two business days after learning of the loss or theft of your card or personal identification code.

- Your loss could be as high as $\$ 500$ if you do not notify the financial institution within two business days after learning of the loss or theft of your card or code.

- If you do not report an unauthorized transfer that appears on your statement within sixty days after the statement is mailed to you, your liability for losses is the amount of any unauthorized transfers that take place between the end of the sixty-day period and the time you notify the financial institution. The financial institution must be able to show that the transfers would not have taken place if you had notified it within the sixty-day period. Your loss could include all the money in your account plus your maximum overdraft line of credit, if you have such a line of credit.

1. For more information on liability limits on credit cards, see "Consumer Handbook to Credit Protection Law" (www.federalreserve.gov/pubs/ consumerhdbk/).
Under the EFTA, if you notify your financial institution of an error involving an electronic fund transfer-including an unauthorized transfer-the institution must promptly investigate and correct the error. If you believe there has been an error in an electronic fund transfer associated with your account,

1. Write or call your financial institution immediately if possible, but within sixty days of the date the institution mailed the first statement that you think shows an error. Give your name and account number, explain why you believe there is an error, describe the error, and state the dollar amount and date in question. If you call the financial institution, you may be asked to send the information in writing within ten business days.

2. The financial institution must promptly investigate an error and generally must resolve it within ten business days. If the institution cannot resolve the error within ten business days, it may take up to forty-five days to complete its investigation. In that case, within ten business days of your notifying the financial institution of the error, the institution must put back into your account the amount in question while it finishes the investigation. If the error involves a new account opened in the past thirty days, the financial institution generally must resolve the error within twenty business days. For a POS transaction, an international transaction, or a new account (if the error could not be resolved within the applicable period), the financial institution may take up to ninety days to complete its investigation.

3. The financial institution must notify you of the results of its investigation. If there was an error, the institution must correct it promptly, for example, by making the re-credit final. If it finds no error, the financial institution must explain in writing why it believes no error occurred and let you know that it will deduct any amount re-credited during the investigation.

Generally, electronic fund transfer products not associated with a consumer bank account, such as stored-value cards, are not covered by the EFTA. For this reason, you should read the documents you receive with a stored-value card to find out about protections as well as any fees for using the card. Some cards can be registered so that if the card is lost or stolen, a replacement can be issued. There may be fees each time you use the card (for example, a fee may be deducted when using the card at an ATM), or there may be a monthly maintenance fee or an inactivity fee (for example, if you don't use the card for twelve months, the balance may be reduced by a set amount each month until the balance is gone). 
such as in a transit system, on a college campus, or at a particular retail establishment, or in "open systems," such as with ATM networks or with any merchant that accepts cards with a MasterCard or Visa logo.

Just as the uses of stored-value cards vary, so too do the features of the cards and the conditions of their use. Users may or may not be charged a fee when they use the card. There may be an expiration date on the funds, or an inactivity fee if the card is not used within a specified period. Some stored-value cards allow consumers to register the card and to review transactions or check balances online. Some card registration programs have a means of reporting lost or stolen cards, thus providing for the recovery of funds (in essence, the issuer deactivates the lost or stolen card and replaces it with an active card); many other programs treat the stored value as cash, and the value remaining on a lost or stolen card may not be recoverable.

Payroll cards. Payroll cards are a paperless mechanism by which an employee's pay is loaded on a stored-value card. For employers, payroll cards facilitate payments to those employees who do not make use of direct deposit, including unbanked employees, and also reduce the cost of replacing lost or stolen paychecks. Employees benefit by not having to pay check-cashing fees, and they may be able to manage their cash flow better because they do not have to cash out their entire paycheck at one time. Payroll funds may be transferred to an individual account for each employee or may be commingled in one company account, with a sub-account for each employee. ${ }^{9}$ In the case of individual accounts, employees may develop a relationship with a bank that could lead to their taking advantage of other products and services. Financial institutions may benefit from an expanded potential customer base and also from fee income associated with these cards.

Fewer than 4 percent of employers reported using payroll cards in 2002, reaching fewer than 1 percent of U.S. households (or approximately one million households), but interest in the cards appears to be growing (in 2003 several large employers began

9. See Samuel Frumkin, William Reeves, and Barry Wides, "Payroll Cards: An Innovative Product for Reaching the Unbanked and Underbanked," Community Developments Analysis, Office of the Comptroller of the Currency, October 2003. With the individualaccount structure, the account is a consumer account and the funds carry FDIC coverage and EFTA consumer protections. FDIC coverage does not automatically apply to the commingled-funds structure (sometimes called an "omnibus account") (www.occ.treas.gov/cdd/ payrollcards.pdf). using payroll cards in lieu of paychecks). ${ }^{10}$ It has been estimated that about 70 percent of the monthly pay loaded on payroll cards is withdrawn in cash at ATMs and that the remainder is used for purchases at points of sale. ${ }^{11}$

Smart cards. Another version of the stored-value card, commonly called a "smart card," has a memory chip or a microprocessor that records the value remaining as the card is used to make purchases. Smart cards have been used since the early 1990s, for example, by participants in federal welfare programs-Temporary Assistance for Needy Families (formerly Aid to Families with Dependent Children) and the food stamp program-to access their benefits at ATMs and at point-of-sale terminals in grocery stores. The largest issuer of smart cards in the United States is now the Department of the Treasury, which uses them to make payments and reimbursements to military personnel worldwide.

Some studies have suggested that smart cards have not been widely accepted by consumers and merchants because they do not offer benefits over other payment instruments and because of consumer concerns about loss and other risks. ${ }^{12}$ However, smart cards have been successfully adopted in some closed settings, such as transportation systems (for example, the Washington, D.C., Metro system), universities, and military bases. Given their success in these environments, smart cards may be more adoptable in niche markets. ${ }^{13}$

\section{USE AND USERS OF E-BANKING}

The use of electronic banking became more widespread among U.S. households between 1995 and 2003 while the proportions of households using traditional (non-electronic) banking methods declined (table 1). Nevertheless, a large proportion of consumers still conduct at least some banking business "in person": More than three out of four households participating in the 2001 Survey of Consumer

10. American Payroll Association, "Employer Payroll Debit Card Survey" (www.americanpayroll.org/pdfs/surveys2003/PayrollDebitCard.pdf); and Ariana M. Moore, "Payroll Cards: A Direct Deposit Solution for the Unbanked" (Celent Communications, December 2002).

11. Moore, "Payroll Cards."

12. See Sujit Chakravorti, "Why Has Stored Value Not Caught On?" Emerging Issues Series (Federal Reserve Bank of Chicago, Supervision and Regulation Department, May 2000); and Brian Mantel, "Why Don't Consumers Use Electronic Banking Products? Towards a Theory of Obstacles, Incentives, and Opportunities," Emerging Payments Occasional Paper Series EPS-2000-1 (Federal Reserve Bank of Chicago, September 2000).

13. Mantel, "Why Don't Consumers Use Electronic Banking Products?" 
1. Percentage of U.S. households that use various electronic banking technologies, selected years

\begin{tabular}{|c|c|c|c|c|c|c|c|}
\hline \multirow{2}{*}{ Technology } & \multicolumn{4}{|c|}{ Survey of Consumer Finances } & \multicolumn{3}{|c|}{ Surveys of Consumers } \\
\hline & 1995 & 1998 & 2001 & $\begin{array}{l}\text { Percent change, } \\
1995 \text { to } 2001\end{array}$ & 1999 & 2003 & $\begin{array}{l}\text { Percent change, } \\
1999 \text { to } 2003\end{array}$ \\
\hline Electronic $^{1}$ & & & & & & & \\
\hline Direct deposit of any type & 53 & 67 & 73 & 38 & 65 & 70 & 8 \\
\hline ATM card ............... & 35 & 55 & 58 & 66 & 59 & 65 & 10 \\
\hline Debit card ............ & 20 & 37 & 50 & 150 & n.a. & 54 & \\
\hline Preauthorized debits ..... & 25 & 40 & 44 & 76 & 31 & 46 & 48 \\
\hline $\begin{array}{l}\text { Automated phone system } \\
\text { Aut }\end{array}$ & n.a. ${ }^{2}$ & 26 & 23 & & 40 & 44 & $\begin{array}{l}40 \\
10\end{array}$ \\
\hline Computer banking..... & 4 & 7 & 21 & 425 & 10 & 32 & 220 \\
\hline Smart card .......... & 1 & 2 & 3 & 200 & n.a. & 6 & $\ldots$ \\
\hline Prepaid card & n.a. & n.a. & n.a. & - & n.a. & 73 & $\ldots$ \\
\hline $\begin{array}{l}\text { Memo: Average number of } \\
\text { electronic technologies } \\
\text { used per household }{ }^{3} \ldots\end{array}$ & 1.4 & 2.1 & 2.5 & 78 & 2.0 & 2.6 & 30 \\
\hline Non-electronic & & & & & & & \\
\hline In person.... & 87 & 81 & 78 & -10 & n.a. & n.a. & \\
\hline Mail …..................... & 59 & 55 & 52 & -12 & n.a. & n.a. & \\
\hline Phone (talk in person) ......... & n.a. ${ }^{2}$ & 43 & 43 & $\ldots$ & n.a. & n.a. & . \\
\hline $\begin{array}{l}\text { MEmo: Average number of } \\
\text { non-electronic technologies } \\
\text { used per household } \ldots . . . . . .\end{array}$ & 1.7 & 1.8 & 1.7 & 0 & n.a. & n.a. & \\
\hline
\end{tabular}

NotE. In this and subsequent tables, the data are for only those households that have an account at a bank, thrift institution, or credit union.

1. The following language was used in the questions to distinguish among debit cards, smart cards, and prepaid cards:

DEBIT CARD. Survey of Consumer Finances: A debit card is a card that you can present when you buy things that automatically deducts the amount of the purchase from the money in an account that you have. Do you/does anyone in your family use any debit cards? Surveys of Consumers: A debit card is a card that you can use when you buy things that automatically deducts the amount of the purchase from an account that you have, like a checking account. Have you used a card that automatically deducts money from an account for a purchase in the past twelve months?

SMART CARD. Survey of Consumer Finances: A smart card is a type of payment card containing a computer chip which is set to hold a sum of money. As the card is used, purchases are subtracted from that sum. Do you/or anyone in your family living here have any such cards that you can use for a variety of

Finances reported that they deal in person with their bank. In the same survey, nearly three out of four households reported using some form of direct deposit (for pay, retirement benefits, or dividends, for example) and nearly three out of five reported using an ATM card.

The proportion of households banking by computer grew fivefold between 1995 and 2001 (threefold between 1999 and 2003), and the proportions using debit cards and smart cards more than doubled. ${ }^{14}$ The proportion of households using preauthorized debits also grew considerably. It is worth noting, however, that despite the rise in the proportions of households using computer banking and smart cards, relatively small proportions of households are using these technologies. Information on the use of prepaid stored-value cards is available only for 2003, when 73 percent of households reported having some experience with these cards, including phone cards and gift cards. The average number of e-banking technologies used per household has

14. Unless otherwise noted, differences discussed in the text are statistically significant at the 95 percent level of confidence or higher.

purchases? Surveys of Consumers: A smart card is a type of payment card that has a computer chip, which is set to hold an amount of money. As you use the card to buy things, the value is subtracted. Smart cards are different than prepaid cards in that you can add money to the card at special machines designed for smart cards or sometimes at ATMs. Have you ever had or used a smart card?

PREPAID CARD. Surveys of Consumers: Prepaid cards are cards that contain a stored value, or a value that has been paid up-front, allowing you to use the card much like cash. As you use the card, the prepaid value is drawn down. Examples of prepaid cards include phone cards, gift cards, and student cards. Have you ever had or used a prepaid card or bought one as a gift?

2. Using an automated phone system and talking to a bank employee over the telephone were not separated in the 1995 Survey of Consumer Finances.

3. For the Surveys of Consumers, the averages are based on only those technologies for which data are available for both years.

n.a. Not available

... Not applicable.

increased in recent years, while the average number of non-electronic means of banking used has remained steady.

To look in depth at who is using e-banking products and services, this analysis focuses on the use and users of three specific technologies-debit cards, preauthorized debits, and computer banking. These three were chosen to represent different types of e-banking technologies at different stages in their development and are technologies that might attract different types of users.

- Debit cards represent the next generation of an existing and familiar technology. They operate as an extension of the widely used ATM card, by allowing consumers to pay for goods at a point of sale by directly debiting a designated bank account (usually a checking account). ${ }^{15}$

- Preauthorized debits represent a passive technology; once consumers sign up for automatic pay-

15. Although vendors are marketing many stored-value cards as "debit" cards, the focus here is on debit cards tied to a consumer bank account. 
ment of a particular bill (a mortgage or utility payment, for example), they need do little more than ensure that funds are in the account by the debit date.

- Computer banking calls for perhaps the most consumer involvement, as it requires the user to maintain and regularly interact with additional technology (a computer and an Internet connection).

Some previous research has suggested that certain demographic characteristics tend to be associated with the adoption of e-banking. For example, several studies have suggested that households with higher levels of income are more likely to use certain technologies. ${ }^{16}$ In general, these studies have also found that younger consumers and those with more education are more likely to use e-banking. Other studies of individual e-banking technologies have shown that, when a range of other variables (age, marital status, gender, race, region, and attitudes) are controlled for, the effects of income and education vary and in some cases are not significant. ${ }^{17}$ Racial and ethnic differences have also been found; some of these differences may be related to accessibility, as some services may be available only in English. ${ }^{18}$

\section{Debit Cards}

Not surprisingly, the typical household that uses a debit card has more income than the typical household that does not (table 2). Also, households using a debit card tend to be headed by someone who is younger than 45 and who has some postsecondary education. Interestingly, in 1998 and 2001 the median

16. Arthur B. Kennickell and Myron L. Kwast, "Who Uses Electronic Banking? Results From the 1995 Survey of Consumer Finances" (paper presented at the annual meeting of the Western Economic Association, Seattle, Washington, July 1997) (www.federalreserve.gov/pubs/feds/1997/199735/199735pap.pdf); Eun-Ju Lee and Jinkook Lee, "Haven't Adopted Electronic Financial Services Yet? The Acceptance and Diffusion of Electronic Banking Innovations," Financial Counseling and Planning, vol. 11, no. 1 (2000), pp. 49-60; Robert Rugimbana, "Predicting Automated Teller Machine Usage: The Relative Importance of Perceptual and Demographic Factors," International Journal of Bank Marketing, vol. 13, no. 4 (1995), pp. 26-32; and Valerie A. Zeithaml and Mary C. Gilly, "Characteristics Affecting the Acceptance of Retailing Technologies: A Comparison of Elderly and Nonelderly Consumers," Journal of Retailing, vol. 63, no. 1 (1987), pp. 49-86.

17. See, for example, Jane Kolodinsky and Jeanne Hogarth, "Closing the Digital 'Age' Divide: Adoption of Electronic Financial Services by Consumers Age 60+," Consumer Interests Annual, vol. 50 (forthcoming 2004).

18. Matthew Josefowicz and Sang Lee, "Ethnic Minorities, Financial Services, and the Web" (Celent Communications, January 2003); and Lee and Lee, "Haven't Adopted Electronic Financial Services Yet?', value of financial assets for households that did not use a debit card was higher than that for households that did use a debit card. This finding represents a change from 1995, when users had a higher median value of financial assets than non-users. And it is consistent with the finding that debit card use between 1995 and 2001 became more widespread among lower-income households; for example, 21 percent of households that used a debit card were in the bottom 40 percent of the income distribution in 1995, compared with 28 percent in 2001. Use also became more widespread among households headed by someone age 45 to 64 , someone with a high school education or less, and someone classified as a minority. Thus, over the years, debit card use has become more "democratized"-that is, users have become more representative of the population as a whole. Nevertheless, it is still the case that households that use debit cards have higher incomes and tend to be headed by younger persons with more education.

\section{Preauthorized Debits}

Households using preauthorized debits tend to have higher incomes and higher levels of financial assets than non-users and to be headed by someone between 35 and 54 years old with at least a bachelor's degree. Over the period 1995 to 2001, the proportion of households using preauthorized debits rose among households with lower levels of assets, households headed by someone 75 or older, someone who had more education (bachelor's degree or higher), and someone who was black. Because preauthorized debits allow consumers to set up automatic bill payments, which may be especially convenient for older consumers, it is not surprising that the median age of users rose over time, from 45 years in 1995 to 47 years in 2001 .

The proportions of households using preauthorized debits to pay utility bills and make housing payments doubled between 1995 and 2001, and the proportion using preauthorized debits to pay another type of bill (for example, to make an auto loan or lease payment) nearly doubled (table 3 ). The proportion using preauthorized debits to make investments or transfers to other accounts held by the consumer also rose over the years.

\section{Computer Banking}

Logic dictates that computer ownership and Internet access are related to adoption of computer banking; 
2. Demographic characteristics of users and non-users of selected electronic banking technologies, selected years

\begin{tabular}{|c|c|c|c|c|c|c|}
\hline \multirow{3}{*}{ Characteristic } & \multicolumn{6}{|c|}{ Debit card } \\
\hline & \multicolumn{2}{|c|}{1995} & \multicolumn{2}{|c|}{1998} & \multicolumn{2}{|c|}{2001} \\
\hline & Users & Non-users & Users & Non-users & Users & Non-users \\
\hline \multicolumn{7}{|l|}{ Household income } \\
\hline 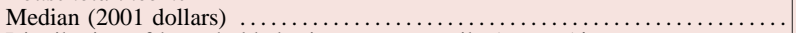 & 47,260 & 36,626 & 48,391 & 36,293 & 51,395 & 37,004 \\
\hline \multicolumn{7}{|l|}{ Distribution of households by income percentile (percent) ${ }^{1}$} \\
\hline 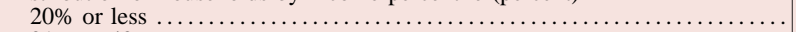 & 7 & 17 & 9 & 18 & 9 & 20 \\
\hline $21 \%$ to $40 \%$......................... & 14 & 20 & 17 & 21 & 19 & 23 \\
\hline $41 \%$ to $60 \%$. & 23 & 21 & 23 & 21 & 22 & 21 \\
\hline 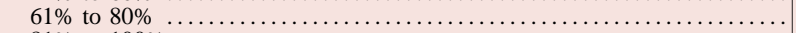 & 28 & 21 & 26 & 19 & 25 & 17 \\
\hline 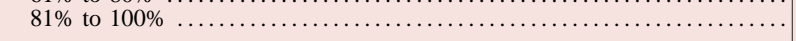 & 28 & 21 & 26 & 21 & 24 & 18 \\
\hline \multicolumn{7}{|l|}{ Household financial assets } \\
\hline 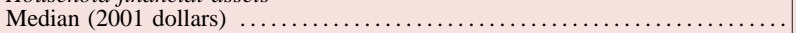 & 21,960 & 18,088 & 25,297 & 27,778 & 26,460 & 32,400 \\
\hline \multicolumn{7}{|l|}{ Distribution of households by financial asset percentile (percent) ${ }^{2}$} \\
\hline 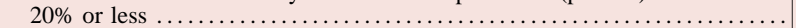 & 8 & 12 & 10 & 15 & 12 & 16 \\
\hline $21 \%$ to $40 \%$.......... & 20 & 22 & 22 & 21 & 24 & 18 \\
\hline 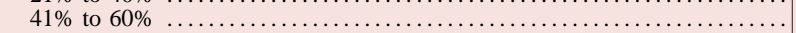 & 24 & 22 & 25 & 20 & 22 & 21 \\
\hline 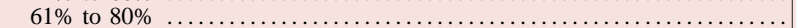 & 25 & 22 & 23 & 22 & 23 & 21 \\
\hline 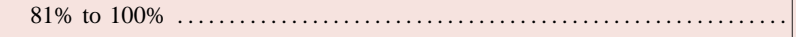 & 24 & 22 & 20 & 23 & 19 & 25 \\
\hline \multicolumn{7}{|l|}{ Age of head of household } \\
\hline 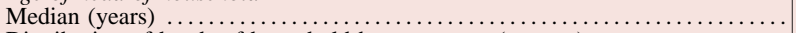 & 40 & 48 & 41 & 51 & 42 & 54 \\
\hline \multicolumn{7}{|l|}{ Distribution of heads of household by age group (percent) } \\
\hline 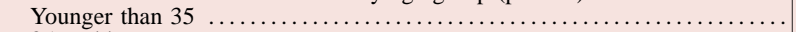 & 33 & 20 & 32 & 16 & 30 & 13 \\
\hline 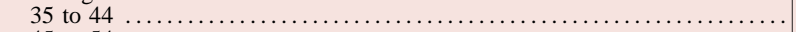 & 29 & 22 & 27 & 21 & 27 & 18 \\
\hline 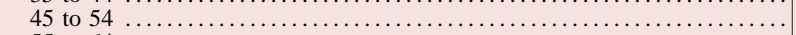 & 18 & 18 & 21 & 20 & 23 & 19 \\
\hline 55 to $64 \ldots \ldots \ldots \ldots \ldots$ & 10 & 13 & 11 & 15 & 12 & 16 \\
\hline 65 to $74 \ldots \ldots$ & 8 & 14 & 7 & 14 & 6 & 16 \\
\hline 75 or older & 3 & 13 & 3 & 15 & 4 & 18 \\
\hline \multicolumn{7}{|l|}{ Education of head of household } \\
\hline \multirow{2}{*}{\multicolumn{7}{|c|}{ Distribution of heads of household by level (percent) }} \\
\hline & & & & & & \\
\hline No high school diploma $\ldots \ldots \ldots \ldots \ldots \ldots \ldots$ & 9 & 18 & 8 & 19 & 10 & 19 \\
\hline High school diploma or GED & 23 & 31 & 26 & 31 & 27 & 32 \\
\hline Some college $\ldots \ldots \ldots \ldots \ldots \ldots$ & 27 & 24 & 29 & 23 & 26 & 21 \\
\hline Bachelor's degree ........... & 22 & 16 & 22 & 15 & 23 & 15 \\
\hline Postgraduate education & 18 & 12 & 14 & 12 & 14 & 13 \\
\hline \multicolumn{7}{|l|}{ Racelethnicity of head of household } \\
\hline \multicolumn{7}{|l|}{ Distribution (percent) } \\
\hline White......... & 81 & 83 & 82 & 81 & 77 & 82 \\
\hline Black .... & 9 & 9 & 9 & 10 & 11 & 12 \\
\hline Hispanic $\ldots \ldots \ldots \ldots \ldots \ldots$ & 7 & 4 & 6 & 6 & 8 & 4 \\
\hline Other $\ldots \ldots \ldots \ldots \ldots \ldots \ldots \ldots$ & 3 & 4 & 2 & 4 & 3 & 2 \\
\hline \multicolumn{7}{|l|}{ Marital status of head of household } \\
\hline \multicolumn{7}{|l|}{ Distribution (percent) } \\
\hline Married .......... & 65 & 60 & 65 & 58 & 66 & 59 \\
\hline Single female ... & 22 & 27 & 21 & 28 & 22 & 27 \\
\hline Single male ........ & 13 & 13 & 14 & 14 & 13 & 14 \\
\hline Employment status of head of household & & & & & & \\
\hline Distribution (percent) & & & & & & \\
\hline Working ........... & 83 & 67 & 84 & 65 & 84 & 63 \\
\hline Retired $\ldots \ldots \ldots \ldots \ldots \ldots$ & 11 & 21 & 9 & 26 & 9 & 28 \\
\hline Unemployed, looking for job .... & 2 & 3 & 2 & 3 & 2 & 2 \\
\hline Unemployed, not looking for job & 4 & 9 & 4 & 6 & 4 & 6 \\
\hline Homeownership status & & & & & & \\
\hline Distribution (percent) & & & & & & \\
\hline Own home $\ldots . . . .$. & 68 & 72 & 68 & 72 & 67 & 76 \\
\hline Do not own home ... & 32 & 28 & 32 & 28 & 33 & 24 \\
\hline
\end{tabular}

NoTE. In this and subsequent tables, percentage distributions may not sum to 100 because of rounding.

1. Income percentiles are based on the income of all responding households in the survey year. Thus, of debit card users in 1995, 7 percent were in the lowest 20 percent of the income distribution in that year and 28 percent were in the top 20 percent.

however, many studies have been unable to control for those variables. Moreover, although access to computers has become more widespread, households may not be using them for banking and other financial management tasks.

Neither the Survey of Consumer Finances nor the Surveys of Consumers specifically identify house-

2. Financial asset percentiles are based on the financial assets of all responding households in the survey year. Thus, of debit card users in 1995, 8 percent were in the lowest 20 percent of all households in terms of financial assets and 24 percent were in the top 20 percent.

SOURCE. Survey of Consumer Finances.

holds that have computers and Internet connections, although the SCF does ask about household use of computers and financial management software to manage money. In 2001, among households that had bank accounts, 19 percent reported using financial management software, and of that group, 49 percent used computer banking (data not shown). In addi- 


\begin{tabular}{|c|c|c|c|c|c|c|c|c|c|c|c|}
\hline \multicolumn{6}{|c|}{ Preauthorized debits } & \multicolumn{6}{|c|}{ Computer banking } \\
\hline \multicolumn{2}{|c|}{1995} & \multicolumn{2}{|c|}{1998} & \multicolumn{2}{|c|}{2001} & \multicolumn{2}{|c|}{1995} & \multicolumn{2}{|c|}{1998} & \multicolumn{2}{|c|}{2001} \\
\hline Users & Non-users & Users & Non-users & Users & Non-users & Users & Non-users & Users & Non-users & Users & Non-users \\
\hline 49,623 & 35,445 & 50,590 & 34,093 & 55,506 & 34,948 & 53,168 & 38,990 & 86,884 & 38,493 & 71,953 & 38,032 \\
\hline 8 & 17 & 8 & 19 & 8 & 20 & 3 & 15 & 5 & 15 & 3 & 18 \\
\hline 14 & 21 & 14 & 23 & 15 & 26 & 12 & 19 & 6 & 20 & 10 & 24 \\
\hline 20 & 22 & 23 & 21 & 23 & 21 & 17 & 21 & 14 & 22 & 19 & 23 \\
\hline 21 & 21 & 26 & 19 & 26 & 18 & 33 & 22 & 19 & 22 & 27 & 20 \\
\hline 31 & 20 & 29 & 18 & 28 & 15 & 34 & 22 & 57 & 20 & 40 & 16 \\
\hline 32,940 & 15,291 & 46,468 & 15,456 & 51,000 & 16,900 & 35,714 & 18,504 & 114,619 & 23,457 & 81,350 & 21,500 \\
\hline 3 & 14 & 6 & 17 & 7 & 19 & 7 & 12 & 4 & 14 & 3 & 17 \\
\hline 20 & 22 & 17 & 24 & 18 & 24 & 16 & 22 & 11 & 22 & 16 & 22 \\
\hline 22 & 22 & 22 & 21 & 21 & 22 & 19 & 22 & 16 & 22 & 19 & 22 \\
\hline 26 & 21 & 27 & 19 & 26 & 18 & 28 & 22 & 23 & 22 & 25 & 21 \\
\hline 29 & 21 & 28 & 18 & 28 & 18 & 30 & 22 & 47 & 20 & 38 & 18 \\
\hline 45 & 46 & 46 & 47 & 47 & 48 & 40 & 46 & 42 & 47 & 42 & 49 \\
\hline 22 & 23 & 21 & 22 & 21 & 22 & 34 & 22 & 34 & 21 & 28 & 20 \\
\hline 26 & 22 & 25 & 22 & 24 & 21 & 23 & 23 & 23 & 23 & 30 & 20 \\
\hline 22 & 17 & 21 & 19 & 23 & 19 & 28 & 18 & 28 & 19 & 26 & 20 \\
\hline 13 & 13 & 14 & 13 & 14 & 13 & 9 & 13 & 12 & 14 & 11 & 14 \\
\hline 12 & 13 & 11 & 12 & 10 & 12 & 6 & 13 & 2 & 12 & 4 & 13 \\
\hline 6 & 12 & 8 & 11 & 9 & 12 & 1 & 11 & 2 & 11 & 3 & 13 \\
\hline 14 & 13 & 14 & 12 & 14 & 12 & 15 & 13 & 16 & 13 & 16 & 12 \\
\hline 11 & 18 & 9 & 19 & 10 & 19 & 4 & 17 & 3 & 16 & 3 & 18 \\
\hline 26 & 31 & 25 & 32 & 25 & 33 & 22 & 30 & 9 & 31 & 17 & 33 \\
\hline 26 & 24 & 27 & 24 & 24 & 23 & 31 & 24 & 21 & 25 & 22 & 24 \\
\hline 21 & 16 & 21 & 16 & 23 & 16 & 24 & 17 & 37 & 17 & 34 & 15 \\
\hline 17 & 11 & 18 & 10 & 18 & 9 & 20 & 12 & 29 & 12 & 25 & 10 \\
\hline 88 & 81 & 84 & 80 & 84 & 76 & 81 & 83 & 84 & 81 & 87 & 78 \\
\hline 6 & 10 & 9 & 10 & 10 & 13 & 15 & 9 & 5 & 10 & 7 & 13 \\
\hline 3 & 5 & 4 & 7 & 4 & 8 & 3 & 5 & 3 & 6 & 2 & 7 \\
\hline 4 & 4 & 4 & 3 & 3 & 3 & 2 & 4 & 8 & 3 & 5 & 2 \\
\hline 69 & 59 & 67 & 57 & 68 & 58 & 65 & 61 & 73 & 60 & 74 & 60 \\
\hline 22 & 27 & 22 & 28 & 21 & 27 & 20 & 26 & 9 & 27 & 13 & 27 \\
\hline 9 & 14 & 11 & 16 & 11 & 15 & 15 & 13 & 18 & 14 & 14 & 13 \\
\hline 77 & 68 & 77 & 69 & 78 & 70 & 89 & 69 & 90 & 71 & 89 & 70 \\
\hline 16 & 20 & 18 & 21 & 16 & 21 & $\begin{array}{l}7 \\
1\end{array}$ & 20 & $\begin{array}{l}5 \\
3\end{array}$ & 21 & 7 & 22 \\
\hline 2 & $\begin{array}{l}3 \\
0\end{array}$ & 1 & 3 & 2 & 2 & 1 & 3 & 3 & 2 & 2 & 2 \\
\hline 5 & 9 & 3 & 7 & 4 & 6 & 2 & 8 & 1 & 6 & 2 & 6 \\
\hline 82 & 67 & 79 & 65 & 80 & 66 & 71 & 71 & 74 & 70 & 77 & 71 \\
\hline 18 & 33 & 21 & 35 & 20 & 34 & 29 & 29 & 26 & 30 & 23 & 29 \\
\hline
\end{tabular}

tion, over the years the SCF has asked respondents whether they use the Internet when making decisions related to credit or borrowing and saving or investing. The proportion that reported using the Internet in making credit or borrowing decisions rose from 12 percent in 1998 to 24 percent in 2001, and the proportion that used the Internet in making saving and investment decisions rose from 9 percent to 16 percent. Data from the 2003 Surveys of Consumers indicate that 95 percent of those who use com- puter banking use it to monitor their accounts, 64 percent use it to transfer funds between accounts, and 55 percent use it to pay bills (data not shown).

Some data on computer and Internet access are available from the Department of Commerce. In a nationwide survey, 66 percent of individuals reported having access to a computer at some location (home, school, office, community center, library, or elsewhere) in 2001, compared with 54 percent in 1997, and 54 percent reported having Internet access in 
3. Percentage of U.S. households that use preauthorized debits for various purposes, selected years

\begin{tabular}{|c|c|c|c|c|}
\hline Purpose & 1995 & 1998 & 2001 & $\begin{array}{c}\text { Percent } \\
\text { change } \\
1995 \text { to } \\
2001\end{array}$ \\
\hline For any purpose $\ldots$. & 25 & 40 & 44 & 76 \\
\hline For utility payment...$\ldots$. & 5 & 9 & 13 & 160 \\
\hline $\begin{array}{c}\text { For mortgage, rent, condo, } \\
\text { or co-op payment } \ldots . . .\end{array}$ & 7 & 10 & 14 & 100 \\
\hline For any other bill or payment & 17 & 28 & 31 & 82 \\
\hline $\begin{array}{l}\text { For investments or transfers } \\
\text { to other accounts } \ldots \ldots \ldots\end{array}$ & 1 & 4 & 3 & 200 \\
\hline $\begin{array}{l}\text { Memo: Average number of } \\
\text { different types of } \\
\text { preauthorized debits used }\end{array}$ & .3 & .5 & 6 & 100 \\
\hline
\end{tabular}

Source. Survey of Consumer Finances.

2001, compared with 22 percent in $1997 .{ }^{19}$ Given the growth in access to computers and the Internet, it is not surprising that the proportion of households that reported using computer banking rose, from 4 percent in 1995 (SCF data) to 32 percent in 2003 (Surveys of Consumers data, table 1). In fact, computer banking was the fastest growing e-banking technology, in terms of the proportions of households using the technology, over the eight years covered by the two surveys.

Access to high-speed Internet connections also may have contributed to the spread of computer banking. In 2002, most home Internet connections were via a standard phone line $(75$ percent, down from 88 percent in 2000); another 17 percent of households connected to the Internet via broadband cable modem (up from 8 percent in 2000), and 5 percent used high-speed DSL (digital subscriber line; up from 1 percent in 2000). ${ }^{20}$ In addition to finding the greater speed more satisfactory, some consumers may feel more secure conducting financial transactions through high-speed Internet access than via slower modem connections.

Households that conducted banking business via computer in 2001 had higher incomes (two-thirds were in the upper 40 percent of the income distribution) and more financial assets than those that did not (table 2). They were also more likely to be headed by someone younger than 55, someone who was white, and someone who had at least a bachelor's degree. Between 1995 and 2001, computer banking spread among those with more formal education (bachelor's

19. U.S. Department of Commerce, National Telecommunications and Information Administration, "A Nation Online: How Americans Are Expanding Their Use of the Internet," February 2002 (www.ntia.doc.gov/ntiahome/dn/index.html).

20. "The UCLA Internet Report: Surveying the Digital Future, Year Three" (report prepared at the UCLA Center for Communication Policy), February 2003 (www.ccp.ucla.edu/pdf/ucla-internet-reportyear-three.pdf). degree or higher) and across a range of ages -35 to 44, 55 to 64, and 75 and over. Although the numbers involved are small, requiring caution in interpretation, the apparent spread of computer banking among those in the oldest age category is interesting.

The increase in the use of computer banking among those in older age groups has a parallel in the use of debit cards. Although users of e-banking technologies tend to be younger than 45 , there is some evidence of wider adoption by older cohorts as time passes. Such evidence is to be expected, as an individual who was, say, 43, in 1995 would have moved to the 45 to 54 group by 2001 . Thus, some spread among older age groups over time would be anticipated and indeed is observed.

\section{CONSUMER PERCEPTIONS AND THE USE OF E-BANKING}

Consumers' acceptance of technological innovations may be influenced not only by their socioeconomic and demographic characteristics, but also by their perceptions of specific technologies and by the characteristics of different products and services. ${ }^{21}$ For example, consumers may be motivated to use some electronic banking technologies because of the perceived convenience and time saving. In one survey of computer banking users, 79 percent indicated that convenience was very important in their decision to use computer banking and 71 percent said that saving time was very important; in another survey, a large proportion of consumers said that twenty-four-hour availability was the most important factor in their use of computer banking. ${ }^{22}$ Other studies indicate that consumers will not adopt a new financial product unless it reduces their costs and does not require them to change their behavior when using it. ${ }^{23}$ Adoption

21. See Fred D. Davis, "Perceived Usefulness, Perceived Ease of Use, and User Acceptance of Information Technology," MIS Quarterly, vol. 1 (September 1989), pp. 319-39; Everett M. Rogers, Diffusion of Innovations (Free Press, 1995); and David Gefen and Detmar W. Straub, "Gender Differences in the Perception and Use of E-Mail: An Extension to the Technology Acceptance Model," MIS Quarterly, vol. 21 (December 1997), pp. 389-99.

22. Susannah Fox, "Online Banking: A Pew Internet Project Data Memo" (Pew Research Center, November 2002) (www.pewinternet.org/ reports/pdfs/PIP_Online_Banking.pdf); and Andrew Lockett and Dale Littler, "The Adoption of Direct Banking Services," Journal of Marketing Management, vol. 13 (November 1997), pp. 791-811.

23. Gloria Barczac and Pam Scholder Ellen, "Developing Typologies of Consumer Motives for Use of Technologically-Based Banking Services," Journal of Business Research, vol. 38, no. 2 (1997), pp. 131-39; and John Beran, Joshua Peirez, and Ronald Prill, "Growth in Electronic Payments: What Are the Opportunities and the Barriers to Success?" (panel discussion at The Payments System in Transition conference, hosted by the Federal Reserve Payments System Development Committee, Washington, D.C., October 2003). 


\begin{tabular}{|c|c|c|c|c|c|c|}
\hline \multirow[b]{2}{*}{ Perception } & \multicolumn{3}{|c|}{ Mean response ${ }^{1}$} & \multicolumn{3}{|c|}{$\begin{array}{l}\text { Percent who agree } \\
\text { or strongly agree }\end{array}$} \\
\hline & 1999 & 2003 & $\begin{array}{c}\text { Memo: } \\
\text { Percent } \\
\text { change, } \\
1999 \text { to } \\
2003\end{array}$ & 1999 & 2003 & $\begin{array}{c}\text { Percent } \\
\text { change, } \\
1999 \text { to } \\
2003\end{array}$ \\
\hline \multicolumn{7}{|l|}{ Convenience . . . . . } \\
\hline 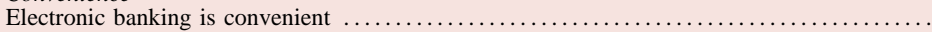 & 3.8 & 3.9 & 3 & 76 & 81 & 7 \\
\hline There are enough advantages of electronic banking for me to consider using it & 3.1 & 3.4 & 10 & 46 & 58 & 28 \\
\hline Electronic banking helps me to better manage my personal finances $\ldots . . . \ldots$. & 3.0 & 3.3 & 10 & 37 & 48 & 30 \\
\hline $\begin{array}{l}\text { It bothers me to use a machine for banking transactions when I could talk } \\
\text { with a person instead } \ldots \ldots \ldots \ldots \ldots \ldots \ldots \ldots \ldots \ldots \ldots \ldots \ldots \ldots \ldots \ldots \ldots \ldots \ldots \ldots \ldots\end{array}$ & 3.2 & 3.1 & -5 & 53 & 46 & -13 \\
\hline \multicolumn{7}{|l|}{ Familiarity and ease of use } \\
\hline Electronic banking is the wave of the future & 3.8 & 4.0 & 4 & 72 & 82 & 14 \\
\hline Electronic banking services are used by many people $\ldots \ldots \ldots \ldots$ & 3.7 & 3.9 & 6 & 70 & 83 & 19 \\
\hline I have the opportunity to try various electronic banking services. & 3.1 & 3.6 & 14 & 49 & 70 & 44 \\
\hline I have seen how others use electronic banking $\ldots \ldots \ldots \ldots \ldots \ldots . . . . .$. & 3.0 & 3.5 & 18 & 41 & 64 & 56 \\
\hline I need to familiarize myself with electronic banking technology . & 3.5 & 3.3 & -5 & 63 & 53 & -16 \\
\hline Electronic banking is difficult to use $\ldots \ldots \ldots \ldots \ldots \ldots \ldots \ldots$ & 2.6 & 2.5 & -5 & 21 & 17 & -17 \\
\hline \multicolumn{7}{|l|}{ Security and privacy } \\
\hline $\begin{array}{l}\text { When I use electronic banking, my money is as safe as when } \mathrm{I} \text { use other } \\
\text { banking services } \ldots \ldots \ldots \ldots \ldots \ldots \ldots \ldots \ldots \ldots \ldots \ldots \ldots \ldots\end{array}$ & 3.2 & 3.3 & 4 & 49 & 55 & 13 \\
\hline $\begin{array}{l}\text { Mistakes with electronic banking are more difficult to get corrected than with } \\
\text { regular banking } \ldots \ldots \ldots \ldots \ldots \ldots \ldots\end{array}$ & 3.3 & 3.3 & -2 & 50 & 49 & -4 \\
\hline Mistakes are more likely to occur with electronic banking than with regular banking ....... & 3.0 & 2.9 & -4 & 41 & 36 & -12 \\
\hline I feel comfortable providing my personal information through electronic banking systems ... & 2.7 & 2.9 & 6 & 35 & 41 & 15 \\
\hline \multicolumn{7}{|l|}{2003 supplemental questions on security and privacy } \\
\hline I worry about the privacy of my information when using electronic banking systems & n.a & 3.5 & & n.a. & 63 & \\
\hline I worry that electronic banking systems are not secure enough to protect my & & & & & & \\
\hline $\begin{array}{l}\text { personal financial information } \ldots \ldots \ldots \ldots \ldots \ldots \ldots \ldots \ldots \ldots \ldots \ldots \ldots \ldots \ldots \ldots \ldots \ldots \ldots \ldots \ldots \ldots \ldots \ldots \\
\text { I worry that electronic banking systems are not secure enough and I could lose }\end{array}$ & n.a & 3.2 & & n.a. & 52 & \\
\hline 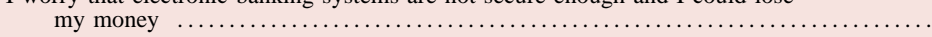 & n.a & 3.0 & . & n.a. & 40 & \\
\hline
\end{tabular}

"strongly agree."

n.a. Not available.

Source. Surveys of Consumers.

has also been associated with a technology's availability and the time required to learn to use it. ${ }^{24}$

Some research has found that perceived ease of use and usefulness is associated with adoption of electronic technologies. ${ }^{25}$ Still other research suggests that a lack of understanding of how specific e-banking technologies operate, of their intrinsic benefits, and of ways to acquire them is associated with lower adoption rates. ${ }^{26}$ One study found a correlation between adoption and consumer desire for control, incentives, privacy, and personal involve-

24. Orazio P. Attanasio, Luigi Guiso, and Tullio Jappelli, "The Demand for Money, Financial Innovation, and the Welfare Cost of Inflation: An Analysis with Household Data," Journal of Political Economy, vol. 110 (April 2002), pp. 317-55.

25. Davis, "Perceived Usefulness, Perceived Ease of Use, and User Acceptance of Information Technology"; Brian Mantel, "Why Do Consumers Pay Bills Electronically? An Empirical Analysis," Economic Perspectives (Fourth quarter, 2000), pp. 32-47; and Jane Kolodinsky and Jeanne Hogarth, "The Adoption of Electronic Banking Technologies by American Consumers," Consumer Interests Annual, vol. 47, (2001) (www.consumerinterests.org/public/articles/ Kolodinsky,_Hogarth.pdf).

26. Federal Reserve Bank of St. Louis, "A Summary of Consumer and Business Attitudes on Direct Deposit and Direct Payment: A National ACH Market Research Study" (Federal Reserve Bank of St. Louis, 1998) (www.stlouisfed.org/financial/assets/ pdf/summary.pdf); and Mantel "Why Do Consumers Pay Bills Electronically?" ment; for example, consumers who perceived a greater value in controlling their payments (such as having the ability to decide when a bill is paid and receiving a receipt of payment) were less likely to use electronic payment. ${ }^{27}$ Finally, research has identified a user-friendly site and consumer confidence in the institution and in network security as important in the decision to use computer banking. ${ }^{28}$

The 1999 and 2003 Surveys of Consumers sought to measure perceptions of e-banking by asking respondents to indicate their degree of agreement or disagreement with a set of statements about electronic banking. The statements generally related to three aspects of e-banking found by some studies to be related to consumer adoption and use of e-banking products and services: convenience, familiarity and ease of use, and security and privacy.

Between 1999 and 2003, consumers' perceptions of e-banking became more positive in all three areas (table 4). Compared with those in 1999, respondents as a whole in 2003 were more likely to agree or strongly agree with positive statements about

27. Mantel, "Why Do Consumers Pay Bills Electronically?"

28. Alenka Grealish, "Online Banking Adoption: Beyond the Tip of the Iceberg" (Celent Communications, November 2002). 
5. Percentage of U.S. households that use various electronic banking technologies, by perception index level, 1999 and 2003

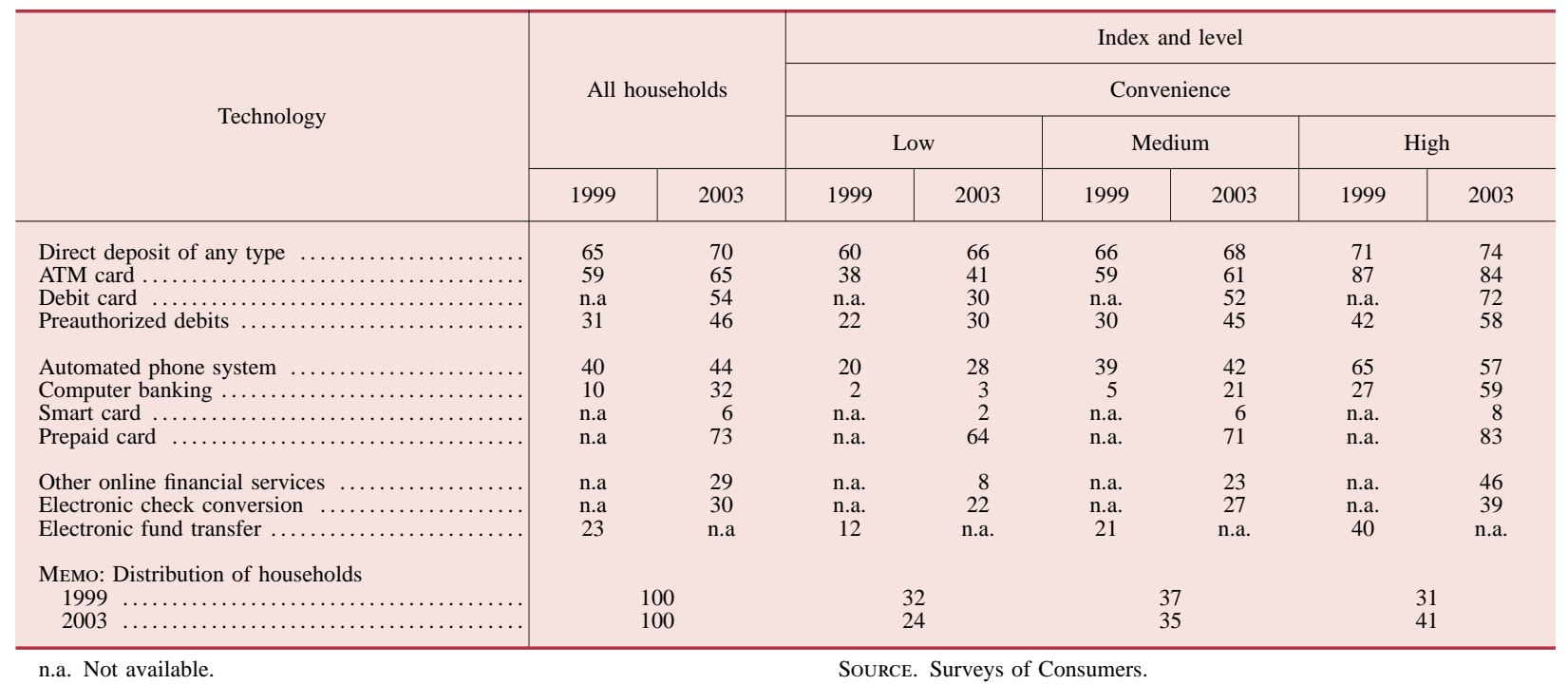

e-banking (for example, "There are enough advantages of electronic banking for me to consider using it") and less likely to agree or strongly agree with negative statements (for example, "Electronic banking is difficult to use"). The greatest changes concerned familiarity with e-banking and its perceived ease of use. For example, more than two-thirds of respondents in 2003 reported having had an opportunity to try various e-banking services, compared with just under half in 1999. With respect to convenience, although more than three-fourths of respondents in both years agreed that e-banking is convenient, fewer than half in both years agreed that e-banking helps them better manage their personal finances.

Respondents were more likely in 2003 than in 1999 to believe that their money is as safe using e-banking as when using other banking services (55 percent compared with 49 percent). They were just as likely to believe that mistakes are more difficult to get corrected with e-banking than with regular banking (49 percent in 2003 compared with 50 percent in 1999). Privacy remains a major concern: Fewer than half of respondents in both years said that they feel comfortable providing personal information through e-banking systems.

To quantify the strength of consumers' perceptions on the three aspects of e-banking associated with adoption-convenience, familiarity and ease of use, and security and privacy - an index was created for each and respondents were placed in one of three groups according to their score on each index: low, score of 50 percent or less on the index; medium, score of 51 percent through 74 percent; and high, score of 75 percent or higher. A higher score indi- cates a more positive perception of that aspect of e-banking. (For information on how the indexes were constructed, see appendix B.)

For each of the three indexes, a larger proportion of respondents were classified as high in 2003 than in 1999, and a smaller proportion of respondents were classified as low (table 5). The convenience index had the greatest proportion in the high group in 1999; by 2003 , the convenience index and the familiarity and ease of use index had nearly equal proportions in the high group. Although the proportion of respondents in the high group on the security and privacy index rose between 1999 and 2003, the proportion remained lower than that for the other indexes. These results suggest that although more consumers believe that e-banking is convenient, have become familiar with e-banking technologies, and believe that the technologies are easy to use, many remain concerned about security and privacy when using e-banking products and services.

In both 1999 and 2003, on each of the three indexes, respondents having low perception scores generally were less likely to be users of these e-banking technologies than respondents having medium or high scores. Over the four-year period, the use of some of the technologies, including computer banking, spread disproportionately among those with high scores. For example, while the proportion of respondents classified as low on the convenience index who used computer banking rose from 2 percent to 3 percent between 1999 and 2003, the proportion classified as high on that index who used computer banking rose from 27 percent to 59 percent. The data are tantalizingly unrevealing as to causes; 
6. Demographic characteristics of households by perception index level, 1999 and 2003

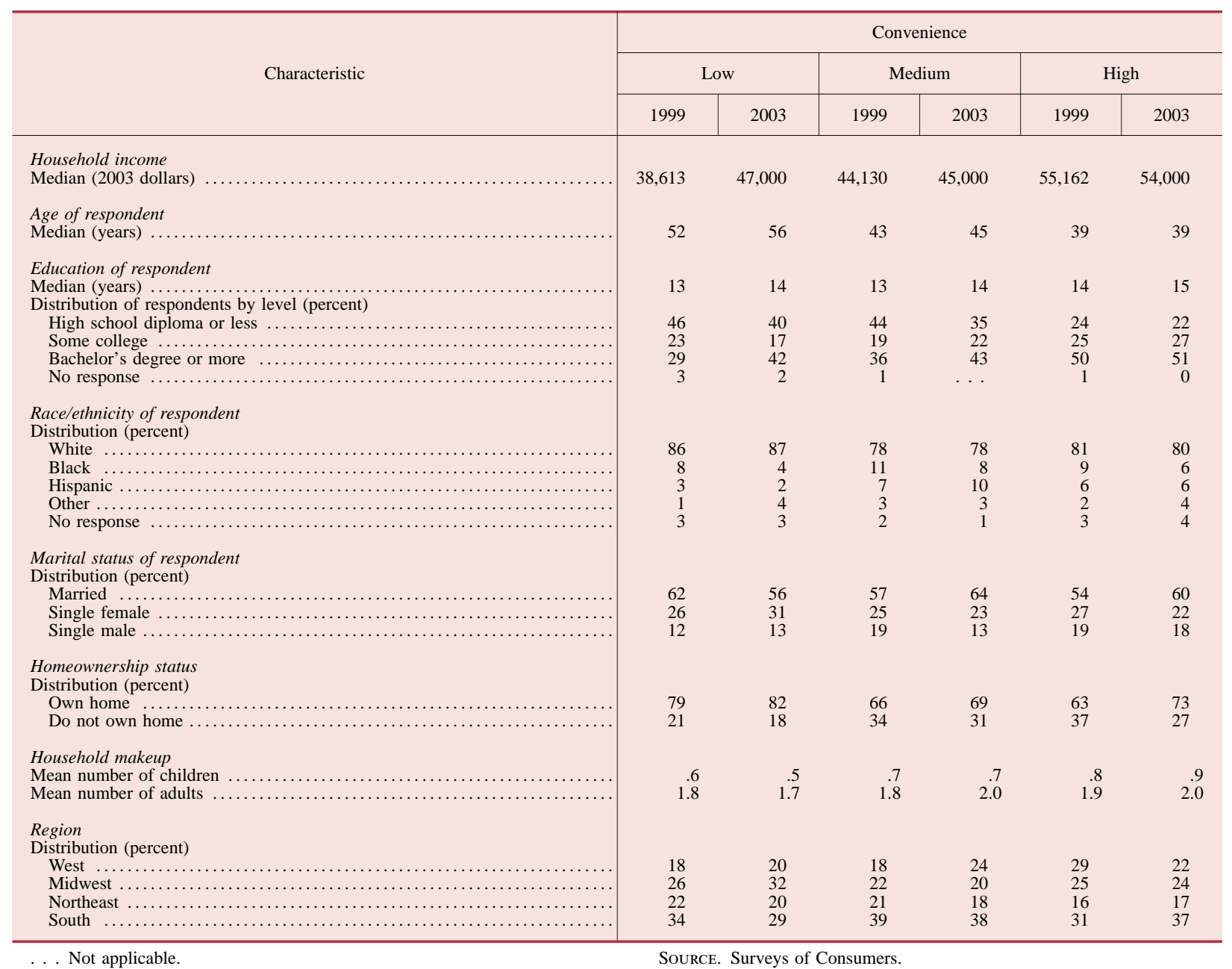

may be accepting of all-electronic accounts, such as the Electronic Transfer Accounts introduced by the Department of the Treasury, as a transition into the financial mainstream.

7. Expectations about future use of selected electronic banking technologies among users and non-users, 1999 and 2003

Percent

\begin{tabular}{|c|c|c|c|c|}
\hline \multirow{3}{*}{ User status and expectation } & \multicolumn{4}{|c|}{ Technology } \\
\hline & \multicolumn{2}{|c|}{$\begin{array}{c}\text { Preauthorized } \\
\text { debits }\end{array}$} & \multicolumn{2}{|c|}{$\begin{array}{l}\text { Computer } \\
\text { banking }\end{array}$} \\
\hline & 1999 & 2003 & 1999 & 2003 \\
\hline Already using and will continue to use & 31 & 46 & 10 & 32 \\
\hline $\begin{array}{l}\text { Current non-user, likely to start using } \\
\text { in next } 12 \text { months } \ldots \ldots \ldots \ldots \ldots \ldots\end{array}$ & 15 & 10 & 22 & 14 \\
\hline $\begin{array}{l}\text { Current non-user, unlikely to start using } \\
\text { in next } 12 \text { months but may use at } \\
\text { some point in the future } \ldots \ldots \ldots \ldots .\end{array}$ & 21 & 15 & 29 & 18 \\
\hline Current non-user, probably will never use & 33 & 29 & 39 & 36 \\
\hline All respondents $\ldots \ldots \ldots \ldots \ldots \ldots \ldots \ldots$ & 100 & 100 & 100 & 100 \\
\hline
\end{tabular}

SOURCE. Surveys of Consumers.

\section{IMPLICATIONS OF E-BANKING} FOR CONSUMER EDUCATION

The patterns of use of e-banking products and services and the changing socioeconomic and demographic characteristics of users present some interesting challenges for those who provide financial education for consumers. The spread of debit cards and preauthorized debits among a broader range of income, asset, age, and education groups is a prime example of these challenges. Although users of debit cards are operating on a cash, rather than credit, basis-something financial planners and consumer educators generally recommend, especially for those having difficulty managing their finances-they may not be using a check register as an accounting device. The challenge for consumer educators is finding ways to help consumers track balances and record debit transactions. Similarly, preauthorized debits are a good financial management tool to help consumers 


\begin{tabular}{|c|c|c|c|c|c|c|c|c|c|c|c|}
\hline \multicolumn{6}{|c|}{ Familiarity and ease of use } & \multicolumn{6}{|c|}{ Security and privacy } \\
\hline \multicolumn{2}{|c|}{ Low } & \multicolumn{2}{|c|}{ Medium } & \multicolumn{2}{|c|}{ High } & \multicolumn{2}{|c|}{ Low } & \multicolumn{2}{|c|}{ Medium } & \multicolumn{2}{|c|}{ High } \\
\hline 1999 & 2003 & 1999 & 2003 & 1999 & 2003 & 1999 & 2003 & 1999 & 2003 & 1999 & 2003 \\
\hline 29,788 & 35,000 & 49,646 & 50,000 & 48,543 & 50,000 & 41,923 & 45,000 & 48,543 & 48,000 & 55,162 & 60,000 \\
\hline 62 & 64 & 44 & 47 & 38 & 41 & 47 & 50 & 41 & 43 & 42 & 41 \\
\hline 12 & 13 & 14 & 14 & 14 & 14 & 13 & 14 & 14 & 14 & 14 & 15 \\
\hline 63 & 44 & 39 & 33 & 26 & 26 & 45 & 38 & 35 & 31 & 29 & 18 \\
\hline 18 & 18 & 18 & 23 & 31 & 23 & 21 & 21 & 22 & 23 & 23 & 25 \\
\hline 16 & 37 & 41 & 44 & 43 & 51 & 31 & 40 & 43 & 45 & 48 & 57 \\
\hline 3 & 1 & 1 & 1 & 1 & 0 & 2 & 1 & 0 & 0 & 1 & $\ldots$ \\
\hline 84 & 84 & 81 & 82 & 80 & 80 & 81 & 79 & 81 & 80 & 84 & 85 \\
\hline 7 & 4 & 9 & 6 & 11 & 7 & 11 & 7 & 9 & 8 & 5 & 4 \\
\hline 4 & 4 & 5 & 6 & 6 & 7 & 4 & 6 & 5 & 8 & 7 & 4 \\
\hline 1 & 6 & 2 & 4 & 2 & 3 & 1 & 5 & 3 & 2 & 2 & 5 \\
\hline 4 & 3 & 3 & 2 & 1 & 3 & 3 & 3 & 2 & 2 & 2 & 3 \\
\hline 55 & 55 & 59 & 62 & 56 & 59 & 59 & 60 & 56 & 61 & 58 & 62 \\
\hline 29 & 34 & 24 & 21 & 28 & 26 & 25 & 23 & 26 & 26 & 26 & 23 \\
\hline 16 & 11 & 17 & 16 & 16 & 15 & 16 & 17 & 18 & 13 & 16 & 16 \\
\hline 81 & 73 & 72 & 73 & 60 & 75 & 73 & 72 & 67 & 72 & 66 & 79 \\
\hline 19 & 27 & 28 & 27 & 40 & 25 & 27 & 28 & 33 & 28 & 34 & 21 \\
\hline .3 & .5 & .7 & .6 & .8 & .9 & .7 & .6 & .6 & .8 & .7 & .7 \\
\hline 1.7 & 1.7 & 1.8 & 1.9 & 1.9 & 2.0 & 1.8 & 1.9 & 1.8 & 2.0 & 1.8 & 1.9 \\
\hline 20 & 17 & 21 & 23 & 23 & 23 & 19 & 24 & 22 & 21 & 26 & 23 \\
\hline 17 & 22 & 27 & 25 & 20 & 25 & 24 & 27 & 26 & 24 & 21 & 23 \\
\hline 19 & 33 & 19 & 17 & 22 & 16 & 19 & 16 & 19 & 18 & 23 & 21 \\
\hline 44 & 28 & 33 & 35 & 36 & 36 & 38 & 33 & 34 & 37 & 30 & 33 \\
\hline
\end{tabular}

pay bills on time (and avoid derogatory data in their credit reports), but they work only if there are enough funds in the account to cover the debit. For consumers who rely on "float" to cover bill payments, managing funds to make certain enough money is in the account becomes very important.

Despite the growing democratization in the use of some e-banking technologies, there is still some evidence that lower-income households are less likely to adopt some of these technologies, at least when it comes to overall financial management. Households that use computers for banking still tend to have higher incomes and more formal education. Although access to computers has become more widespread, households are not necessarily using them for banking, and many are not using them for other financial management tasks or comparison shopping. Consumer educators could help low- and moderateincome families understand how to use computers and the Internet for a wide range of financial management tasks, including computer banking, account management, and comparison shopping for financial products and services.

Stored-value cards hold the promise of being a helpful cash management tool, but they also present some challenges to users in the areas of tracking remaining balances and understanding the terms and conditions of the cards. Some cards can be registered so that a lost or stolen card can be replaced, but others have no such provision, meaning that a lost card is the same as lost cash. Some cards charge fees-for example, an inactivity fee that could be assessed monthly until the balance on the card is used up. Consumer educators need to encourage consumers to learn about the terms and conditions of the stored-value cards they use and understand how they can get the most value from them, be they gift cards, phone cards, or payroll cards. 


\section{CONCLUSION}

Data from the Survey of Consumer Finances and the Surveys of Consumers show a consistent increase over the past eight years in the proportion of consumers using a variety of electronic banking technologies, from such long-available products and services as ATM cards and direct deposit to such newer technologies as debit cards and computer banking. The use of some products, particularly debit cards, has become more democratized over time, but it is still the case that most e-banking products tend to be used by higher income, higher asset, younger, and better educated households.

In light of the growth in the proportion of consumers using e-banking technologies, it may not be surprising that the annual volume of electronic payments was expected to exceed the volume of checks for the first time in 2003. ${ }^{30}$ However, not all banking services may be adaptable to electronic delivery. For a variety of reasons, some related to the product and others to consumer preferences, delivery channels for some products will probably remain more traditional. For example, although the number of online mortgage applications has risen in recent years, consumers may prefer personal contact with financial institution staff when engaging in complex transactions such as mortgages. ${ }^{31}$

E-banking technologies are continuing to evolve, and many new products and services are on the horizon. The Department of the Treasury, for example, which is moving toward an all-electronic Treasury, has several new programs in place or in planning stages. For example, it provides the U.S. Debit Card, a mechanism for delivering nonrecurring payments to individuals and enabling federal government employees to access cash as part of their official duties. The Treasury is also replacing coin and currency in circulation on military bases, ships, and other locations worldwide with stored-value cards. ${ }^{32}$ In addition, the Treasury is considering a plan to stop issuing paper savings bond certificates and to instead

30. Remarks by Chairman Alan Greenspan, The Payments System in Transition conference, Washington, D.C., October 29, 2003 (www.federalreserve.gov/boarddocs/speeches/2003/20031029/ default.htm).

31. Gerard Prendergast and Norman Marr, "Challenging Human Interaction in the Delivery of Banking Services: New Zealand as a Microcosm of European Banking in the Future?" Journal of Euromarketing, vol. 4, no. 1 (1994), pp. 83-98.

32. See Congressional Budget Office, "Emerging Electronic Methods for Making Retail Payments" (Congressional Budget Office, 1996) (ftp://ftp.cbo.gov/0xx/doc14/Elecpay.pdf); and "FMS' Electronic Commerce Initiatives," FMS Fact Sheet (www.fms.treas.gov/ news/factsheets/ec.html). issue electronic savings bonds. Consumers would purchase the savings bonds online instead of at financial institutions, and the bonds would be stored electronically, as Treasury bills, notes, and bonds are currently.

E-banking technologies hold the promise of helping families manage their money, pay their bills on time, and avoid overextending themselves with credit. To take full advantage of these technologies, consumers need to be aware of the evolving array of e-banking technologies available to them and to understand how different technologies fit with their financial management needs. Financial planners and consumer educators, working with both families and financial institutions, can help this promise become a reality.

\section{APPENDIX A: SOURCES OF DATA}

The data on which this article is based come from two nationally representative surveys - the triennial Survey of Consumer Finances and the monthly Surveys of Consumers. Although the surveys have different sampling schemes and differ in some other ways, the data from the two are sufficiently comparable to give a general picture of consumer use and perceptions of electronic banking technologies. Data from the two surveys were not combined for analysis; rather, a separate analysis was carried out on each data set, and the results in some discussions were viewed together to extend the period of analysis and thus get a better idea about trends.

In general, the terms "households," "consumers," "families," and "respondents" are used interchangeably in discussions of the data and elsewhere in the article. To be specific, however, data from the Survey of Consumer Finances are for what was referred to as the "primary economic unit," defined as an economically dominant single individual or couple (married or living as partners) in a household and all other individuals in the household who are financially dependent on that individual or couple. For example, in the case of a household composed of a married couple who own their home, a minor child, a dependent adult child, and a financially independent parent of one of the members of the couple, the primary economic unit would be the couple and the two children. Data from the Surveys of Consumers are for "families," defined as any group of persons living together who are related by marriage, blood, or adoption or any individual living alone or with a person or persons to whom the individual is not related. 


\section{Survey of Consumer Finances}

The Survey of Consumer Finances (SCF) is a triennial survey of U.S. families (defined as primary economic units, as noted above) sponsored by the Federal Reserve, in cooperation with the Internal Revenue Service, Statistics of Income Division, and conducted by NORC, a national organization for research at the University of Chicago. ${ }^{33}$ The survey provides detailed information on U.S. families' balance sheets, use of financial services, demographics, and labor force participation. The great majority of interviews were conducted in person, although interviewers were allowed to conduct telephone interviews if that was more convenient for the respondent. Interviewers used a program running on laptop computers to administer the survey and collect the data. Respondents were encouraged to consult their records as necessary during the interviews.

To gather information that is both representative of the U.S. population and reliable for those assets concentrated in affluent households, the SCF employs a dual-frame sample design consisting of a standard, geographically based random sample and an oversample of affluent households. Weights are used to combine data from the two samples so that the data from the sample families represent the population of all families. ${ }^{34}$ A total of 4,299 households (representing 99.0 million families) were interviewed for the 1995 survey; 4,309 households (representing 102.6 million families) for the 1998 survey; and 4,449 households (representing 106.5 million families) for the 2001 survey. Missing data-missing because of lack of response to individual interview questions, for example - are imputed by making multiple estimates of the missing data to allow for an estimate of uncertainty.

The analysis was restricted to those households that reported having an account with a bank, thrift institution, or credit union. For the 1995 survey, this group constituted 87.6 percent of households; for the 1998 survey, 90.5 percent; and for the 2001 survey, 90.9 percent.

33. See Arthur B. Kennickell, "Wealth Measurement in the Survey of Consumer Finances: Methodology and Directions for Future Research" (paper prepared for the annual meetings of the American Association for Public Opinion Research, Portland, Oregon, May 2000) (www.federalreserve.gov/pubs/oss/oss2/papers/measurement.pdf) and references cited therein.

34. See Arthur B. Kennickell, "Revisions to the SCF Weighting Methodology: Accounting for Race/Ethnicity and Homeownership" (Board of Governors of the Federal Reserve System, January 1999) (www.federalreserve.gov/pubs/oss/oss2/papers/weight.revision.pdf).

\section{Surveys of Consumers}

The Surveys of Consumers, initiated in the late 1940s by the Survey Research Center at the University of Michigan, measures changes in consumer attitudes and expectations with regard to consumer finance decisions. ${ }^{35}$ Each monthly survey of about 500 households includes a set of core questions. For the October and November 1999 and June and July 2003 surveys, the Federal Reserve Board commissioned additional questions concerning households' use and perceptions of electronic banking technologies. Some of these additional questions were based on questions in the Survey of Consumer Finances to allow for comparison of responses to the two surveys.

Interviews were conducted by telephone, with telephone numbers drawn from a cluster sample of residential numbers. The sample was chosen to be broadly representative of the four main regions of the country-Northeast, Midwest, South, and West-in proportion to their populations. Alaska and Hawaii were not included. For each telephone number drawn, an adult in the family (as previously defined) was randomly selected as the respondent. The surveys yielded data from 1,000 respondents in 1999 (October and November surveys combined) and 1,002 respondents in 2003 (June and July surveys combined). The collected data were weighted to be representative of the population as a whole, thereby correcting for differences among families in the probability of their being selected as survey respondents. All survey data in the tables are based on weighted observations.

As with the Survey of Consumer Finances, the analysis was restricted to those households that reported having an account with a bank, thrift institution, or credit union. For the 1999 survey, this group constituted 87.1 percent of households, and for the 2003 survey, 85.5 percent.

\section{APPENDIX B: E-BANKING PERCEPTION INDEXES}

The additional questions asked in the 1999 and 2003 Surveys of Consumers (see appendix A) included a set of positive and negative statements about electronic banking, such as "Electronic banking helps me to better manage my personal finances" and "Mistakes are more likely to occur with electronic banking

35. See Richard T. Curtin, "Surveys of Consumers," for more information on sample design, questionnaire development, and interviewing protocols (http://athena.sca.isr.umich.edu/scripts/info/ info.asp). 
than with regular banking." Respondents were asked to indicate their level of agreement or disagreement with each statement on a five-point scale, from "strongly disagree" to "strongly agree."

The statements were grouped into three sets reflecting characteristics found by earlier research to be associated with adoption of electronic technologies: convenience, familiarity and ease of use, and security and privacy. ${ }^{36}$ These three sets of statements were used to create three indexes of perceptions of electronic banking. The statements that make up each of the indexes are shown in table 4. The additional statements about security and privacy included only in the 2003 surveys were not used in the security and privacy index.

Each respondent's view of e-banking on each perception index was rated as high, medium, or low. First, each response was assigned a numerical value -5 for strongly agree, 4 for agree, 3 for neutral, 2 for disagree, and 1 for strongly disagree. Then, because some statements were positive (for example, "Electronic banking is convenient") while others

36. See Davis, "Perceived Usefulness, Perceived Ease of Use, and User Acceptance of Information Technology"; and Mantel, "Why Do Consumers Pay Bills Electronically?" were negative (for example, "Electronic banking is difficult to use"), the responses to the negative statements were reversed to a positive scale. For example, a response of "strongly agree" to the statement "Electronic banking is difficult to use," which was initially assigned the numerical value of 5, was recoded as a response of "strongly disagree" with the statement's opposite ("Electronic banking is easy to use") and thus was assigned a value of 1 . This recoding of responses to negative statements meant that higher scores reflected more-positive attitudes toward e-banking. For example, a total score of 20 on the convenience index, which is made up of four statements, would indicate a very positive perception-a "strongly agree" response to each of the four statements.

Finally, each respondent's total score on each index was calculated as a percentage of the maximum possible score on that index-20 on the convenience index, 30 on the familiarity and ease of use index, and 20 on the security and privacy index. Households having a score of 75 percent or higher were classified as "high," those scoring 51 percent through 74 percent were classified as "medium," and those scoring 50 percent or lower were classified as "low." 